\title{
The Observational Microeconomics Study of the Phenomenon of Entrepreneur Resilience and Collaborative Innovative Financial Leadership in the United States
}

http://doi.org/10.21272/fmir.4(3).24-41.2020

\section{Eric Brown,}

DBA, Entrepreneur/Investor, Detroit, USA

Karina Kasztelnik, ORCID: https://orcid.org/0000-0002-1090-3700

Professor of Accounting, Colorado State University-Global Campus, Aurora, CO, USA

\begin{abstract}
The main purpose of the research is to complete the observation of the phenomenon of entrepreneur resilience and collaborative innovative financial leadership in the United States. Starting a new business is a demanding, and stressful process creating significant changes in a business owner's life (Yang \& Danes, 2015). Due to the financial crisis in 2007-2008, chapter 9 bankruptcy in 2013, and the current insufficiency of jobs in Detroit, Michigan, many individuals had to start their microbusiness. Detroit, Michigan suffered the most extensive municipal bankruptcy filings in American history with a debt estimation close to twenty billion dollars (Washburn, 2015). The methodology is the observation all current and prior existing literature and facts available for the purpose of understanding the current phenomenon of entrepreneur financial innovation leadership. Many entrepreneurs did not have a choice but to start their own business in Detroit, Michigan. Today, entrepreneurs are stressed out, because of the lack of resources needed to provide for themselves and their families while striving to grow their business. If entrepreneurs are not resilient and innovative leadership, they will not survive. This research study confirms and theoretically proves that there is a strong need for microbusiness owners to gain more insight into the relationship between entrepreneur resilience and financial innovation leadership to survive and grow their business. Winterhalter et al. (2016) stated that smaller firms lack the resources of larger organizations to invest in financial innovation leadership to grow their business. Smallbone et al. (2012) stated that small businesses are commonly considered less resilient than larger businesses due to lack of resources, bargaining power, and are unable to spread risk across a large customer base. The critical review study can be useful for the entrepreneurs around the globe.
\end{abstract}

Keywords: Resilience, Financial Innovation.

JEL Classification: D91, D04, D79, O36.

This work is licensed under a Creative Commons Attribution 4.0 International License

Cite as: Brown, E., Kasztelnik, K. (2020). The Observational Microeconomics Study of the Phenomenon of Entrepreneur Resilience and Collaborative Innovative Financial Leadership in the United States. Financial Markets, Institutions and Risks, 4(3), 24-41. http://doi.org/10.21272/fmir.4(3).24-41.2020.

(C) The Authors, 2020. This article is published with open access at Sumy State University.

\section{Introduction}

At the core of strong financial leadership is the ability to understand how programmatic and administrative decisions are likely to impact the organization's financial health. Bulmash (2016) stated in the field of psychology researchers have researched the resilience concept for over 50 years, yet there is little empirical literature in the entrepreneurship field. The authors pointed out in the context of entrepreneurship literature resilience focus on a response to difficulty, a personality trait, quality, or the ability of the entrepreneur (Danes, Lee, Amarapurkar, Stafford, Haynes \& Brewton, 2009; Hayward, Forster, Sarasvathy \& Fredrickson, 2010). Their study looked at resilience as a dynamic process, not as an asset for facing difficulty. They applied a different positive light for resilience as a catalyst for individuals to start the entrepreneurial process itself. However, it did not proactively focus on resilience concerning growth nor considered microbusinesses in cities. There is an active call for researchers to analyze resilience in entrepreneurship literature (Shepherd, 2015; Awotoye \& Singh (2017) and microbusiness growth (Gherhes, Williams, and Vorley, 2016). This led the 
researcher to the problem to what extent, if any there is a relationship between resilience and financial innovation in the microeconomics business market in the state of Michigan in the United States. The literature review provides a concentrated analysis of the phenomenon of entrepreneur resilience in microbusiness and reveals several emerging themes. This section expounds on the themes that emerged including entrepreneur resilience, microbusinesses, society problems, coworking spaces, business development, social capital, financial innovation, and collaborative financial leadership.

Entrepreneur Resilience. Awotoye and Singh (2017) investigation of the term entrepreneur resilience exposed there is little empirical research on the term. This term evolved historically from being researched as an individual entrepreneur's traits (Busenitz \& Barney, 1997; Carland, Hoy, Boulton, \& Carland, 1984). This approach failed to reveal entrepreneurs' behaviors and decisions making which resulted in other approaches considered (Gartner, 1988; Mitchell et al., 2002). Next up was the psychological processes of entrepreneurs (Shaver \& Scott, 1991) then to entrepreneurial cognitions (Baron, 1998; Baron \& Ward, 2004; Mitchell et al., 2002). Today, empirical literature moved on to connect psychological resilience to entrepreneurship based on three common themes adversity, positive adaptation, and risk or uncertainty.

Awotoye and Singh (2017) argued that psychological resilience is worth exploring in the entrepreneur context. It fits inside of the concept of entrepreneurial resilience which reveals the reason why some entrepreneurs quite in the face of different challenges while others continue in the face of uncertainty and risk (p.29). Finally, the authors express their thoughts on entrepreneurial resilience which they define as the ability to overcome highimpact entrepreneurial challenges and persist in the entrepreneurial process in the face of adverse situations and unexpected outcomes. The authors argued their studies' uniqueness was in defining entrepreneurial resilience outside of the general contexts of other fields and defining it in the entrepreneurs-specific field. Their article focused on survival and success for entrepreneurs' yet left out entrepreneurs' resilience relationship to growth in microbusinesses. Awotoye and Singh (2017) stated this evolution had created a rich opportunity for research in the growing focus area of entrepreneurial cognitions in the entrepreneurship literature. This paper strives to fill this gap in the literature by analyzing entrepreneur resilience relationship with financial innovation in a microbusiness economy in the state of Michigan in the United States.

Shepard (2015) called for exploring entrepreneurial cognition in entrepreneurship literature reveals the relevance of this study. Gherhes, Williams, and Vorley (2016) stated Shepard (2015) call should be extended to include microbusinesses growth in their literature review on the difference between microbusiness and SMEs. Shepard (2015) made a unique proposal that cognitive research can be extended and complemented by a more interactive perspective. This interaction he believes would provide more insight into better opportunities for entrepreneurs, more benefits to communities around these potential opportunities, and mutual adjustment based on the two. Therefore, our research on entrepreneur's resilience about growth took a further unique strength through Shepard (2015) article to use entrepreneurs in coworking spaces in the city of Detroit, Michigan to fill this interaction gap in the literature, which will be discussed further in the section on coworking spaces

Fletcher and Sarkar (2013) article is unique by looking beyond the adverse events that could reveal individuals resilence and to a more positive view to describe certain favorable circumstances as adversity such as the birth of a child or marriage which triggered life changes or adjustments. The authors argued these events could provoke an individual to use resilience characteristics and cause the entrepreneur to adapt. This research is unique in that it examines the benefit of the positive change of entrepreneurs with microbusinesses buying inexpensive coworking spaces in the city of Detroit, Michigan, and coping with positive adverse events in them. The different ethnic groups, backgrounds, and pace of work, along with the benefits of potential collaboration between microbusiness to stimulate growth. This environment could be a possible key to entrepreneurs' growth and microbusiness growth by defining their relationship with resilience and financial innovation.

Resilience origins arrived in the clinical developmental psychology long-term study of high-risk children (Masten, 2002; Petrowski, Wintermann, Schaarschmidt, Bornstein, \& Kirschbaum, 2013; Svendsen, Baine, Northridge, Campbell, \& Metcalf, 2014), the conclusion revealed the term "resilience" (Fletcher \& Sarkar, 2013; Malkoc \& Yalcin, 2015). Immediately following researchers paid close attention to positive psychology, which led to this phenomenon entrepreneur resilence for the last several years. Malkoc and Yalcin (2015) stated the studies were to determine psychological well-being focusing on an individual's determination to live purposeful lives, self-acceptance, and relationship with others. Researchers who tackle this perspective on positive psychology argued it enables an individual's potential for personal growth. Personal growth is 
important for business growth. No one will ever strive to grow a business they do not think they can run unless they have in mind an exit strategy to sell the business. A unique perspective that needs more light shed on it in entrepreneur literature. For example, Van Pragg (2003) study puts the complete microbusiness success or failure in the hands of one person the entrepreneur stating, "the man makes the difference: he sets the conditions, the boundaries, the characteristics, and ultimately, the value-creating ability of the newly founded firm" (p.1).

Xing and Sun (2013) revealed the focus of the early research on resilience was to observe and find protective factors that protected individuals from the tension they encountered and to separate those who were able to adapt better to the stress they experience and others who were unable to. In the 90 s there was a tremendous shift in the research done on resilience from a protective factor to searching out how individuals overcome adversity (Fletcher \& Sarkar, 2013; Luthar et al., 2000).

The understanding of the phenomenon resilience has made significant advancements in understanding individuals' functionality in demanding situations. Today, resilience has been studied in several disciplines, such as education, business, law enforcement, communities, sports performance, and the military (Berman, Jonides, \& Kaplan, 2008; Day \& Gu, 2007; Galli \& Vealey, 2008; Gloria, Faulk, \& Steinhardt, 2013; Kam \& Palmer, 2011; Pangallo, Zibarras, Lewis, \& Flaxman, 2015; Riolli \& Savicki, 2003; Robertson, Cooper, Sarkar, \& Curran, 2015). According to Luthar et al. (2000) definitions enable us to interpret the nature, scope, and meaning of a phenomenon.

The word resilience means to leap back in Latin (Merriam-Webster). Pearsall et al. (2006) define resilience as the ability to withstand or recover quickly from difficult conditions. Sarkar and Fletcher (2014) recognized resilience in the context of individuals is founded on two specific concepts which are adversity and positive adaptation. Seligman (2011) stated a resilient person has optimism, reviews circumstances accurately, and can adjust when needed in his/her life. Researchers confirm that for an individual to be resilient, they must endure adversity and exercise positive adaption (Masten, 2001; Rutter,1985; Sarkar \& Fletcher, 2014). Davydov, Stewart, Ritchie, and Chaudieu (2010) stated the adversity that resilient individuals can overcome has different levels or degrees.

Mild adversity is considered stress in one's personal life or at work. These types of difficulty are not the types to involves resilience, such as job loss, homelessness, and death of loved ones, which are much more severe types of adversity (Davydov et al. 2010). Moreover, Fletcher and Sarkar (2013) revealed that adversity is not just something that takes place in negative events but during the positive events as well such as the birth of a child, promotion, or marriage. The authors pointed out the need for individuals to use resilience traits in these situations which causes them to adapt. The first part of the concept of resilience in adversity.

The second part of resilience is a positive adaptation. Luthar et al. (2000) define positive adjustment as "...behaviorally manifested social competence, or success in meeting stage-salient developmental task (2000)." Masten and Obradovic (2006) revealed resilience is internal well-being. For individuals to be considered resilient they must be able to adapt while dealing with adverse stressors. These individuals are considered survivors and overcomers. Entrepreneurs in microbusiness have several things they have to deal with such as starting a new business because of job loss, lack of funds in business that is needed to provide for the family, or family growth without any business growth to spend more time with them.

Sine, Haveman, and Tolbert (2005) pointed out entrepreneurship survival depends on several factors within and outside of the entrepreneur's control. The entrepreneur is going to make the final decision that is going to help the firm grow or die. Ireland \& Miller (2004) stated, the entrepreneurs' experience and cognitions then play a major role in what they decide to do; which is heavy burdens entrepreneurs carry that goes unnoticed by others and even themselves at times. Entrepreneurs that gain insight and understanding about the hardships of entrepreneurship; stress, and the potential of business failure might have a better chance at presenting it. Alphander, Carter, and Forsgren (1990) revealed ten most critical problems that cause firm failure, bankruptcy, and business closure: Accessing funding, recruiting managers, hiring new managers, employee's issues, product pricing, planning for market expansion, legal issues, ensuring quality, and dealing with government agencies. How entrepreneurs cope with these challenges and the stress of running their business raises their chances of firm failure, bankruptcy, and business closure. Linnenluecke (2015) study shows resilience as a coping mechanism to help entrepreneurs overcome stress and business challenges.

Awotoye and Singh (2017) argued entrepreneur resilience diminishes the negative impact that causes hardship and stress, such as the more entrepreneurial resilience they have, the better they can overcome failure in 
business. Therefore, entrepreneurs in microbusinesses must consider becoming more resilient to cope with the stress of running their business, to bounce back from economic setbacks, and to deal with uncontrollable uncertainties/risk. Awotoye and Singh (2017) stated this is a mostly unexplored cognitive process that could help unlock the mysteries of successful entrepreneurship.

Resilience began to be recognized worldwide in the context of children with good development outcomes despite their challenges (Garmezy, 1996; Werner, 1995). Masten (2014) revealed the importance of resilience has evolved over several disciplines. Researchers have studied resilience with: adolescent, teachers and students, managers and employees, military personnel, communities, governments, social systems, and disaster planning (Selignman, 2011, McAllister \& McKinnon, 2009, Tempski et al., 2012, Brown et al., 2001, Richardson, 2002, Welsh, 2014, Lew, 2014). The phenomenon of resilience is widely accepted in the child development literature based on risk, life stressors, or adaptation to risk dealing with protective factors (Olsson et al., 2003).

Connor and Davidson (2003) article revealed resilience as a stress-coping mechanism. Measuring resilience in entrepreneurs is a problem for scale developers (Ahern et al., 2006). One well-accepted measure of resilience is the Connor-Davidson Scale Resilience (2003). To develop the Connor-Davidson Resilience scale content was drawn from many sources. Kobasa, (1979) items reflecting control, commitment, and change viewed as a challenge. Rutter (1985) strong self-esteem/confidence, adaptability when coping with change, social problemsolving skills. Lyons et al. (1991) items were assessing patients and the ability to endure stress or pain and Shackleton's experiences, based on the role of faith and a belief blessed intervention. It is a 25 -item assessment that measures resilience as a function of three interrelated components. The components are personal competence, acceptance of change, trust, control, and spiritual influences (2003). This instrument is valid and accepted in high regard amongst researchers (Windle, Bennett, and Noyes, 2011). Overall, Awotoye (2017) stated there remain many unexplained processes that are related to the behavior and decisions of entrepreneurs, which has created a rich opportunity for research in the growing focus area of entrepreneurial cognitions which embodies resilience, especially in microbusiness. Microbusinesses are needed, and more and more people will need to start microbusiness as technology advances. The new cars driving themselves, the grocery markets that can scan items once you pull them off the shelf and add it to your account. With the need, there is a need for innovative drivers to sustain these microbusinesses due to the lack of resources

SME's Growth. Houston and Reuschke (2017) stated there is little empirical evidence on microbusiness's growth in cities. Mason and Harrison (1985) revealed the need for further research to focus on small businesses ' growth based on the influence of their location or environment (Penrose, 1995). O'Farrel and Hitchens (1988) article revealed this is a need in research because smaller firms depend more on external factors than larger firms. Potter and Moore (2000) argued this gap in research has emerged from the urban economic theory which has overlooked organizations size and focused on larger firms. Houston and Reuschke (2017) address this gap by looking at microbusiness's growth in cities and stated how costly it could be for small businesses to rent in the city but neglected to look at shared space locations in cities many entrepreneurs in microbusiness have migrated to.

Houston and Reuschke (2017) stated microbusiness (those employing fewer than ten people) had been overlooked in urban economic development thinking which focuses more on larger firms. He suggested further research should investigate a cities location to other economic outcomes such as financial innovation for growth (p.54). Winterhalter et al., (2016) stated smaller firms lack the resources of larger organizations to invest in financial innovation to grow their business. Zach (2017) article revealed collaboration for financial innovation is a major driver for microbusiness's success yet suggested further research on other drivers of financial innovation such as entrepreneurship need to be investigated. There is a strong need for entrepreneurs in microbusiness to find more drivers of financial innovation to grow (Roper \& Hewitt-Dundas).

Researchers have pointed out microbusinesses are distinctive in nature compared to larger firms and in some ways, this hinders their ability to grow (Anyadike-Danes et al., 2015). Two ways are; first, they suffer from the lack of resources (Houston \& Reuschke, 2017) this makes innovating difficult (Winterhalter et al., 2016). Second, a psychological threshold needs to be cross for entrepreneurs in microbusinesses to grow (2017), yet some have argued microbusinesses lack resilience (Doern, 2017). Bristow\& Healy (2017) reveal the relationship between financial innovation and resilience remains complex and merits further research.

Resilience is a relatively new topic in business and has been considered to promote business survival or growth following a crisis (Doern, 2017), yet it is underexplored (Awotoye \& Singh, 2017). Empirical evidence on the relationship between resilience and financial innovation still lacks (2017), especially in microbusiness. No 
existing quantitative analysis examines this relationship in a shared (coworking space) location to my knowledge. The literature review will reveal several emerging themes to shed light on microbusiness's growth. This section expounds on the themes that emerged including society's problems, entrepreneur resilience, coworking spaces, business development, social capital, financial innovation, and collaborative financial leadership.

Society's problems. The last few years Detroit, Michigan has promoted collaborative workspaces for entrepreneurs with microbusinesses to help turn its economy around. Since the economic catastrophe that hit Detroit, Michigan in 2008 that devasted its economy, it has been looking for ways to become more resilient and innovative to help businesses survive and grow. There is a growing concern about declining United States businesses as entrepreneurship and economic dynamism has continued to decline in recent years (Hathaway \& Litan, 2014, Singh \& Ogbolu, 2015). Awotoye (2017) article revealed small businesses had created the most jobs in the US economy in the last several decades, yet most new businesses fail within the first two years of operations. Korkmaz (2017) stated, after such a strong economic crisis, Detroit, Michigan has been desperately in need of an economic revival. Bonnet, El Harb, \& Gazzah, (2017) suggested stimulating microbusinesses creation should be considered to spur economic development in disadvantaged regions.

Detroit, Michigan was one of the cities hit the hardest by the economic catastrophe in 2008 and is still striving to recover by focusing intently on collaborative workspaces for entrepreneurs with microbusinesses to help turn their economy around. There is little to no empirical research is done to date that reveals if these social, friendly, and energetic environments help entrepreneurs become more innovative to grow their business (Woods, 2017). Castilho and Quandt (2017) stated coworking spaces are gaining worldwide attention due to its collaborative phenomenon in a social networking economy which is founded on knowledge and continuous financial innovation.

In 2017, thousands of individuals lost their jobs due to several big chain retailers' closures and online business's success (Hendren, 2017). This will lead to more and more individuals seeking to start and grow their new businesses to avoid becoming impoverished due to the lack of jobs especially in Detroit, Michigan. There is a financial crisis that is going on right now that is going to push entrepreneurs to become more resilient and more innovative to survive and grow their businesses. Companies such as Walmart and Amazon are wiping out competition left and right and we are dealing with monopolies today that will force individuals to start their own business to avoid poverty.

Alpander, Carter, and Forsgren (1990) identified 10 most critical problems faced by firms in their first few years 1 . Securing new customers 2. Accessing funding 3. Recruiting managers 4. Hiring managers 5. Dealing with existing employee issues 6. Product pricing 7. Planning for market expansion 8. Dealing with legal issues 9. Ensuring quality and 10. Dealing with various government agencies. These ten things can lead to significant setbacks including, firm failure, bankruptcy, business closure, and loss of customers. These ten critical problems reveal the need for entrepreneurs to strive to become more resilient and take more of a collaborative approach to overcoming these obstacles in the first years of business.

Coworking Spaces. Entrepreneurs in the Detroit area must be willing to trust other entrepreneurs who are experts in different fields to benefit their organization. Coworking spaces could be a tremendous help to microbusinesses to become more innovative. Castilho and Quandt (2017) revealed coworking spaces nurture business ecosystems which grants the potential for knowledge sharing and opportunities for financial innovation in organizations. Zach (2016) suggested future research on the effects of other financial innovation drivers on collaboration for financial innovation such as entrepreneurship needs to be investigated. The ability for entrepreneurs to be willing to collaborate with other entrepreneurs could drive resilience in entrepreneurs which leads to innovative ideas. This research could suggest a more collaborative environment produces more needed networking, collaboration to innovate, and quicker growth opportunities for microbusiness owners.

Paxton and Van (2015) article expressed how important it is to collaborate to develop a mindset that supports creativity and financial innovation. Charlesworth and Shenoy (2016) stated the number of coworking freelancers and small business owners has seen incredible growth over the last few years, almost doubling every year. The convenience, cost efficiency, and energetic environments of most coworking spaces have attracted many small business owners. Castilho and Quandt (2017) stated collaboration also enables entrepreneurs in organizations to adapt quickly to changing economic environment and depend more on social interactions with other entrepreneurs that results in innovative results. 
Stumpf (2013) article mentioned the reason to join a coworking space is to access the space itself, direct contact, the different events, and the sense of community or home that it provides. Ross and Ressia (2015) extended those reasons with four aspects that interest individuals in coworking spaces: "1) Flexible, associated with a good working environment and a broader macro-social economic reality. 2) The attractiveness of flexible alternatives to working from home or in a corporate building. 3) Opportunity to build relationships and social interactions. And 4) Opportunity to collaborate with others on projects and related skills into practice." Out of these four the last two strikes a chord to create more resilience in entrepreneurs.

Castilho and Quandt (2017) extended the list on collaborations to add factors that influenced it and associated indicators: 1) flexibility, involves continuous adjustments of expectations around different perspectives in high-tension interactions. 2) Reciprocity, a continuous building of social ties, developed around positive expectations of trust and reciprocity. 3) Congruence, shared vision based on clear expectations, goals, roles, and responsibilities that brings a sense of identity. 4)Access, people who have access to information. 5) Mobilization, the leader ensures the legitimacy to manage resources and manage tensions that are inherent to collaboration. 6) Transparency, informal interaction lines among members using information channels molded transparency 7) Selflessness, degree of support and mutual aid in the workplace, which is revealed in the interdependence of individuals 8) Self-sufficiency, movements of affirmation between individuals and areas, considering the need for autonomy and preservation and 9) Sharing, the process of exchange and combination of shared interests (2017). This list reveals the benefits behind coworking spaces that microbusinesses can take advantage of to grow their business.

Waters-Lynch and Potts (2017) stated what sets coworking spaces apart from other spaces for work and learning is its complex social concept. Coworking spaces allow entrepreneurs to work in what is called a "good neighbors" and "good partners" environment (Spinuzzi, 2012). Good neighbors are where entrepreneurs and freelancers work alone on their specific task not disturbing or interacting with others. Good partnering is when entrepreneurs are working together with other entrepreneurs in shared spaces actively fostering the trust necessary which leads to collaboration on projects. Coworking spaces give entrepreneurs that are introverts the opportunity to build relationships, collaborations, and the opportunity to gain partnerships to grow their business. These types of opportunities are invaluable and could stop microbusinesses from go out businesses in the first two years such as most of them do.

Cstilho and Quandt (2017) reveal a more thorough list of new collaboration factors which include: 1) Trust at first, creation of a trustful field that supports the building of trustful relationships. 2) Being an Individual, a personal positive perception about life that brings a fearless behavior towards the others supported by trust and creativity. 3) Recommendation, a favorable statement of confidence suitable for the third part as a path to building a relationship. 4) Purpose, determination of doing something intentionality around a specific effort linked to the desired result. 5) Self-awareness, knowledge, and awareness of one's character, including feelings and behaviors. 6) Concentration, the condition, or the ability to be focused on a particular task without being distracted. 7) Self-Determination, able to freely decide and conduct one's development as an individual 8) Being collective, a flow of emerging interactions between individuals sustained by a field of vulnerability and trust 8 ) Belongingness, the act of being a member attending the need to give and receive attention to or from the others. 9) Co-creation, the collective energy that brings different parties together to produce a mutually valued outcome. 10) Partying, a social gathering for pleasure and amusement rich with meaningful experiences. 11) Friendship, goodwill as a quality of being with others. 12) Interdependence, awareness of mutual reliance between individuals and organizations. This list of 12 fits into four distinct intervening factors, enabling knowledge-sharing, enhancing a creative field, supporting a collective action to effective execution, and enhancing an individual acting for the collective. The access, transparency, sharing, and reciprocity along with recommendations fit into the enabling knowledge sharing factor. The flexibility, opening, partying, cocreation, belongingness, being collective, trust at first, and friendship fits into the enhancing a creative field factor. The mobilization, congruence, concentration, purpose, and interdependence fits into supporting a collective action to an effective execution factor. The selflessness, self-sufficiency, being an individual, selfdetermination, and self-awareness fits into enhancing an individual acting for the common factor. These factors reveal the ability of coworking spaces to be more innovative and resilient to survive and grow their business.

Spinuzzi (2012) suggested that social interaction in coworking spaces will provide collaboration and financial innovation which is hard from home or a traditional office environment. Merat and Bo (2013) stated coworking spaces provide an environment where ideas amongst a group of energetic coworking group which supports creativity, financial innovation, and entrepreneurship. Anand and Singh (2011) article focused on links based 
on open knowledge and financial innovation in the knowledge management literature. Parrino (2013) article reveals the benefits of physical proximity amongst coworkers which has the potential to build relationships that lead to increased knowledge.

Business Development. Microbusiness is unique and different from most firms, especially in their business development processes. Parry (2007) stated microbusinesses are more conservative, lack routines and detailed systems, and function with non-formalized methods for business development. Moreover, Kelliher and Reinl (2009) study revealed microbusinesses apply direct supervision and use a one-person centered organizational structure in their business. Business development in microbusinesses almost is always centered around the entrepreneur and their cognitive abilities (Degravel, 2012), who decides the financial leadership practices the organization would apply (Braidford, 2015). Achtenhagen, Ekberg, and Melander (2017) article revealed the lack of research centered around business development in microbusiness and stated how important it is for entrepreneurs to gain more insight on business development to apply it in their businesses to grow and to create more job and economic welfare.

In the United States, an impressive $87.95 \%$ of all organizations are microbusiness (as of 2008; Association for Enterprise Opportunity, 2010). Hartel and O' Connor (2014) stated overlooking the importance of the overall context in which business development happens in microbusinesses is unfortunate theoretically and practically. Entrepreneurs and the society as a whole could benefit from microbusiness development and growth. Microbusinesses are the backbone to economies worldwide and their growth helps the economic welfare of many nations (EIM Business \& Policy Research, 2009.) Burgers, Van den Bosch \& Volberda (2008) study reveals what most of the literature on business development to date tends to focus more on larger organizations highlighting corporate entrepreneurship. Nevertheless, the literature on business development overall is limited (Knyphausen-Aufsess, 2007; Eidhoff \& Poelzl, 2014).

The concept of business development in an organization has appeared as an external-oriented extension of the internal current business practices (Achtenhagen, Ekberg, \& Melander 2017). Pollack (2012) definition of business development as long-term value creation. Forsman (2008) study used the frequently used concept of business development as adding a new line of business while focusing on business development being carried out in projects like fashion with ongoing practices within the organization. Microbusinesses typically carry out their business development with its usual business activities due to its small size. Therefore, this study insight will not benefit microbusinesses along with other researchers who shared this same context of business development (Janovics \& Christiansen, 2003; Burgers et al., 2008; Littunen \& Virtanen, 2009).

Janovics and Christiansen (2003) study focused on business development as an ongoing activity that studied personality characteristics necessary for specific roles in the business development process. This study revealed success in implementation came as a result of being less innovative and more methodical, whereas been more creative and less systematic brought success at idea generation. They suggested putting together teams with these different roles could be a success factor for business development (2003). Microbusinesses usually do not have this type of option seeing that they are running an operated by one individual the owner(manager) with few or no employees. Eidhoff and Poelzl (2014) there is an increasing need for organizations to develop business models that are sustainable in dynamic environments. Entrepreneurs in micro-business development are important to help them grow from a microbusiness to a small business.

Davidsson et al. (2010) reveal several researchers have suggested further research on business development. Achtenhagen, Ekberg, \& Melander (2017) stated the process for developing microbusinesses has a greater need when comparing similar streams of literature. This literature which focuses largely on corporate entrepreneurship focuses only on larger organization settings and neglects business development in smaller firms (Sharma \& Chrisman, 1999; Phan et al., 2009). A related but still limited piece of literature can on financial innovation in microbusinesses. Achtenhagen, Ekberg, \& Melander (2017) stated the understanding behind how microbusiness financial innovation begins remains scarce. Simpson (2001) suggested a cognitive perspective on entrepreneurs could further our understanding of how financial innovation in microbusinesses creates value.

Ireland et al. (2001) stated value creation is a critical performance measure and related to business growth. Although financial performance measures are used often in strategic management studies they do not always prove the well-being of an organization especially those who strive towards idea generation and have patented developments. These organizations are not in a rush to have a million sales they are developing their products, 
services, and app to win big financially in the long run. Heshmati (2001) article revealed microbusiness's challenges need more research to understand them. Reid (1989) mentioned microbusiness's lack of data readily available causes them to go under-researched. The larger organization has tons of data researchers that can be to conduct critical analysis, yet microbusinesses data must be searched out and new data needs to be collected.

Researchers have typically looked at microbusinesses growth in a retrospective design investigating one or numerous external or internal factors impacted on business growth as an outcome measure. Growth is summed up to be operationalized as numbers of employees, increase in sales, and profits and assets (Weinzimmer et al., 1998; Delmar, 1997). However, Penrose (1959) article zoom in on another factor of growth increase in improvement of quality along with an increase in size as a result of the process of development. Over fifty years have passed since then, and researchers are now taking a closer look at this proposal as Nason and Wiklund (2015) agreed with Penrose (1959) quality improvement along with the number of employees are positively related to business growth.

Penrose's work has caught the attention of many researchers in academia, nevertheless only the first definition of growth and increase in amount has seemed to catch on throughout the years until now. Achtenhagen, Ekberg, \& Melander (2017) article focuses on Penrose's second definition of growth as a process of development in microbusinesses. They argued the outcome measures of growth fail to capture factors of growth the practitioners considered relevant which view business development as only one dimension of growth. The process-related articles of business development to this day searching to help organizations grow to remain limited. Microbusinesses owners need to find more ways to improve their business processes and progress to survive and thrive in this competitive global market yet there are little to no studies that can give them practical application to help.

Kind and von Knyphausen-Aufsess (2007) article is one of the few studies which discusses explicitly business development as a process of development in SME settings. This qualitative study investigated a business developer employed in a biotech venture which reveals three categories in the process towards business development. 1) Individuals intended to create value along with revenue potential for the organization. 2) Individuals designed to build relationships with different stakeholders and 3) Individuals intended to produce products and technologies for commercialization (Kind and von Knyphausen-Aufsess, 2007). Nevertheless, a resilience that can grow in entrepreneurs (Awotoye \& Singh, 2017) has limited research as a factor of business development.

Social Capital. The concept of social capital is gaining more and more attention in several studies discussing organizations. It is becoming the glue that holds organizations together. Nahapiet and Ghoshal (1988) define social capital as the combined resource of an organization obtained through its viable relationships with other organizations. Agyapong and Poku (2017) stated that microbusiness that benefits from social capital add to their innovativeness by an increase in product development, customer relationships, and market development, among others. More extensive businesses tend to take more advantage of social capital than microbusiness owners who are at times so tied down carrying out the full duties of their business on their own. Coworking spaces could benefit microbusiness by creating an environment for them to develop social capital amongst those individuals they workaround regularly.

Camps and Marques (2011) stated the social capital within an organization hinges on three different groups the high, medium, and lower accountability groups. The dimensions of social capital reflect on the various groups that are recognized here. Researchers view social capital from two different perspectives content and process. Carr and Shaw (2008) stated these dimensions of social capital are structural, relational, and cognitive in the content perspective. These three works simultaneously together feeding off of one another. Agyapong and Poku (2017) revealed the structural dimension, cognitive and relational proportion benefits one another. Nahapiet and Ghoshal (1998) stated from the process perspective there are four drivers behind social capital: stability, interdependence, closure, and interaction. Social capital in the context of entrepreneurs is more important than many realize. It can lead to microbusinesses growth through collaboration, financial innovation, knowledge sharing, partnering, and sustainability.

Agyapong and Poku (2017) stated researchers had discovered a strong and positive relationship between social capital and the firm's sustainability. Rooks, Szirmai, and Sserwanga (2009) stated to gain the benefits of social networks in its totality it is critical for entrepreneurs to develop strong ties with social, business, and personal relationships. Relationships build over time the more an organization interacts with one other organization. This concept of social capital sheds new light on coworking spaces for new entrepreneurs and microbusiness 
owners to take advantage of. Florin et al. (2003) study revealed that social capital increases the opportunity for businesses to obtain resources that could help improve their performance. Social capital for microbusinesses in an open environment could help them survive by building new relationships they would not have in a closed environment. New relationships bring new insight, understanding, and could help day to day operations of the business run more smoothly to promote growth within the organization.

Ofori and Sackey (2010) result revealed social capital has a significant effect on organizational performance. Researchers have found that organizations with higher social capital tend to report higher firm performance and efficiency than organizations with low social capital (Agyapong and Poku, 2017). Microbusinesses tend to operate as a one-man show or one-man operation and social capital can become detrimental to entrepreneurs in microbusinesses to help them survive. It is no secret that microbusinesses are failing to survive, and few make it past the first two years of their organization opening. Fafchamps and Minten (2002) stated social capital has been found to reduce the cost of transactions which eventually helps generate excellent efficiency results for the organization. Social capital has been able to help organizations in several ways: develop better communication, improve stock management, more efficient collective actions, as well as better access to capital for business growth (Adler \& Kwon, 2002; Hansen, 1999; Leana \& Van Buren, 1999).

Carmona-Lavado, Cuevas-Rodriguez, and Cabello-Hedian (2010) stated the social network of organizations has a positive effect on financial innovation. The social capital theory suggests that certain factors of internal and external social relationships exhibit learning resources, which develop financial innovation within organizations (Adler \& Kwon, 2002). Agyapong and Poku (2017) article revealed social capital has a positive effect on the level of financial innovation in microbusinesses. Cooke and Wills (1999) stated that creating social capital enhances financial innovation due to the knowledge performance of an organization. Moreover, Carrasco-Hernandez and Jimenez-Jimenez (2013) article revealed the social relationship between organizations and employees increase financial innovation development in organizations. Over and over again studies are revealing the importance of social capital in an organization to boost performance, sustainability, and increase financial innovation. These factors are important for larger organization and they are critical for smaller firms and microbusinesses. Unfortunately, many microbusinesses have tried to become innovative and survive on their own. There is a strong need for entrepreneurs in microbusinesses to understand the importance of social capital which can be produced in a coworker space collaborative environment inexpensively compared to other ways.

Tsai and Huang (2008) article revealed social capital helps increase confidence and high levels of trust among employees. Trust is needed when entrepreneurs desire to become more innovative to grow their organization. Trust is built over time and is earned as employees witness firsthand the honesty, integrity, work ethics, and interact with other employees. The same is true in a collaborative environment with freelancers and other entrepreneurs workings side by side to carry out their individual goals. Relationships do not have to grow in these environments, nevertheless when they are it could end up producing social capital which in turn will benefit the organization. Once these relationships are established and parties become engaged with one another this carries over to a new idea and knowledge exchange among others which ends up in an ideal generation and business solutions (Subramaniam \& Youndt, 2005).

Researchers reveal that microbusiness growth is firmly connected to the innovative performance of the organization (Vu Hoang Nam, 2014; Zerenler, Hasiloglu, \& Sezgin, 2008). It seems the more microbusiness collaborate or interact with other organizations the more innovative they become. Len, Chen, and Kuan-Shun Chiu (2010) define financial innovation capability as the ability of organizations to grip and use external information for implementing new knowledge. Financial innovation can look at as a process or an output, nevertheless both of these perspectives of financial innovation influence the performance of microbusinesses (Rosenbusch et al., 2011). Agyapong and Poku (2017) stated financial innovation has become a necessity in the competitive global landscape today and without financial innovation organizations have the highest probability of collapsing.

Financial innovation is critical for microbusiness. Jalali et al. (2013) stated microbusinesses that innovate more end up with more growth, than microbusinesses that innovate less. Financial innovation makes microbusinesses unique which eventually ensures a competitive advantage over other microbusinesses (Kim $\&$ Mauborgne, 1997). The connection between social capital and financial innovation stems from the resources of individuals in and outside of the firm which ends up being the growth engine of the firm (Stam \& Elfring, 2008; Subrahmanya, Mathirajan, \& Krishnaswamy, 2010; Uzkurt, Kumar, Semih Kimzan, \& Eminoglu, 2013). 
This connection reveals the importance of looking deeper into drivers of financial innovation in collaborative social environments.

Financial innovation. Christensen (1998) stated financial innovation plays an important role in economies by helping businesses grow, enabling competitive advantages, and even improving the quality of life. Zach (2017) reveals this is the reason researchers have searched to find more drivers that encourage and manage financial innovation. Definitions for financial innovation vary from disruptive (radically new) to continuous(incremental) improvements to the approval of a new idea (Robertson, 1967) which builds from past financial innovation or promotes new financial innovation (Abernathy \& Clark, 1985). Connor (2003) credited financial innovation is a firm's ability to come up with new ideas that add value to their firm. This is the definition of financial innovation this research will be based on.

Winterhalter et al., (2016) stated smaller firms lack the resources of larger organizations to invest in financial innovation to grow their business. Rajput (2011) study revealed financial innovation help firms create a competitive advantage, especially when searching for new opportunities to grow. Kumar (2007) stated that the ability of entrepreneurs to adapt to innovate through the different business environment are factors that result in success in microbusiness. The absence of these abilities will leave microbusiness with a hard time to survive in the globally competitive marketplace.

Roper and Hewitt-Dundas (2017) stated little is known about the nature of financial innovation among microenterprises with less than 10 employees due to their exclusion from the majority of financial innovation surveys. This weakens researchers understanding of the benefits of financial innovation, especially when it comes to the importance of a firm's collaboration for financial innovation (Laursen \& Salter 2006). Microbusiness operates uniquely compared to larger firms in their innovative process (Cohen \& Klepper 1996), investments in R\&D (Baumann \& Kritikos, 2016), and when collaborating (Kim \& Vonortas, 2014). Allinson et al., (2014) suggested entrepreneurs over microbusinesses could over-estimate the risk connected with chasing growth and financial innovation. This is a prime example of some researchers' suggestions for microbusinesses to partner (or collaborate) with other businesses to offset some of the risks that are associated with innovating to grow their business (Roper \& Hewitt-Dundas, 2017; Hargadon).

Caroll (1983) suggested seeking knowledge and resources outside of the organization could be a good way of limiting microbusiness's risk. Moreover, Powell (1998) stated collaboration could reduce risk and at the same time accelerate or upgrade the quality of financial innovation while promoting more innovative activities. Leiponen and Helfat (2010) stated networking and the eternal relationship could potentially increase the useful knowledge necessary to help firms. Roper et al., (2008) suggested knowledge gain from external sources complemented internal knowledge in building financial innovation performances. Nevertheless, Chesborough (2010) argued that collaborative financial innovation hurts microbusinesses due to their lack of capacity to both seek and absorb external knowledge. Moreover, Laursen and Salter (2014) revealed microbusinesses have a hard time protecting knowledge and appropriate its returns. Paxton, D., \& Van Stralen, S. (2015) study stress how pivotal collaboration is for developing a mindset that supports creativity and financial innovation. Researchers have gone back and forth on the thought between external and internal knowledge to benefit microbusiness, yet this debate in research continues.

Bengtsson et al., (2015) suggested further studies are needed to explain whether smaller firms in an open financial innovation context, are more specialized than large firms, and are therefore able to benefit more from open financial innovation. Some have argued microbusinesses have the most to gain from open financial innovation to overcome the lack of internal knowledge resources (Narula, 2014). Whittaker, Fath, and Fielder (2016) stated allowing open financial innovation may cause partnerships that help microbusinesses share the risk, become more competitive, and increase their resources. Hewitt-Dunbas and Roper (2017) stated finding the right partners can be costly for a microbusiness. Therefore, entrepreneurs over microbusinesses in coworking spaces could be extremely valuable to build trust, comradery, and potentially even partnership to help their company become more innovative to grow.

Entrepreneurs in Microbusiness must become more innovative to help their businesses survive. Korkmaz, K. A. (2017) stated, the economic crisis has resulted in the loss of funding for the operation of Detroit's CDC (Community Development Corporations) which are responsible for urban growth of the area. Winterhalter et al. (2017) stated, firms in emerging markets have used frugal financial innovation and low-cost business models which produce great value for customers at a lower cost. Frugal financial innovation and low-cost 
business models could potentially benefit the microbusiness market as well by producing better value at a lower price to help their market growth.

Collaborative Financial Leadership. Financial innovation requires more than the creative capacities to invent new ideas; it requires managerial skills (leadership) and talents to transform good ideas into practice (Mohr 1982). Zach (2017) study findings that the effect of leadership is far more important than internal organizational settings for financial innovation in microbusinesses. Valdiserri and Wilson (2010) stated entrepreneurs who lack leadership skills to guide the employees, motivate them, and inspire them will have a hard time surviving in business. Moolenburgh (2015) stated collaborative leaders harness diversity, they have the tools and skills that can turn conflict and difference into creative tension, which delivers solutions. Collaborative financial leadership could indeed be a great style of leadership for microbusiness owners to develop in share space environments to grow their business. The failure rates in entrepreneurship suggest that it is not an easy process (M. Van Praag \& Versloot, 2008) solutions are needed and collaborative leadership could be a factor that helps more microbusinesses grow.

Karpel (1973) master's thesis Patterns of Leadership and Facilitation in a Collaborative Task-Oriented Group is likely to be the origins of collaborative leadership. He researched collaborative leadership in small groups of 10-15 (microbusiness are typically 1-10 employees). His study focused on the absence of formal hieratical leadership and the different patterns that evolved in groups. Karpel (1973) study revealed five different factors of collaborative leadership that are defining traits of this style of leadership which he termed Facilitation. They are power-sharing and participation, developing people, creating a character, working with others relationship building, and non-hierarchy leadership.

Power-sharing and participation: "leadership in collaborative groups ideally involves some notion of shared responsibility and influence, accomplished through the voluntary and maximal participation of each member" (p. 14); "the most important lesson any individual or group must learn if they wish to employ a collaborative approach is that their willingness to share all responsibility and to participate as fully as possible is the only base upon which real collaboration can succeed" (p. 177).

Developing people: "[leadership in collaborative groups] try to be conscious of the processes of the group in the pursuit of its goals, and is concerned with maximizing the satisfaction, development, and self-esteem of its members through their participation in the group" (p. 14). Creating clarity: Karpel thought the group he was studying failed to create clarity, 55 leading to a lack of progress: "the clear definition of the goals of the group would constitute one major criterion of movement" (p. 94). Working with others/relationship building: "success depends not just on the performance of the initiator, but on the participation of every group member" (p. 96); it must encompass "a two-way influence process, a reciprocal relationship" (p. 96).

Non-hierarchical leadership: "to succeed collaboratively, members must feel that it is their responsibility to get things done; they must be willing to take risks and assume responsibility to a much higher degree than if they were in a hierarchical group" (p. 178). Mattessich, Murray-close, and Monsey's seminal work (2001) break down the concept of collaborative leadership as a genuine unbiased well-defined relationship entered into by two or more organizations. Included in the relationship is a covenant commitment with clear cut goals, jointly developed structure, and shared responsibility. Last but not least collaborative leadership includes shared authority, accountability, resources, and rewards during success (p.22). Chrislip and Larson (1994) reveal collaborative leadership from another perspective as a unique kind of leadership: leaders who endure high levels of stress, encourage social interaction, and safeguard the process.

Chrislip and Larson (1994) work laid a foundation for collaborative leadership by revealing the doctrine of collaborative leadership. The doctrines are: 1) Inspire commitment and action. 2.) Lead as the peer problem solver. 3.) Build broad-based involvement.4.) Sustain hope and participation. 5.) Servant leadership. 6.) Leadership as a process (Chrislip \& Larson, 1994, p 130). These are the qualities and attributes of a collaborative leadership style. Microbusiness owners tend to do everything themselves and neglect to look at the big picture. They dive in to start their business not understanding the need to apply a leadership style that will help them survive and grow their business. Many microbusinesses have had problems scaling up their business and many researchers point the figure at resources and complain about the lack of resources in small businesses. Nevertheless, researchers tend to neglect to look at other possibilities such as a collaborative leadership style approach for microbusiness in coworking spaces that can generate financial innovation to help them grow their business. Collaborative leadership brings individuals together for a common goal when other 
solutions appear to fail. The coworking spaces environment is perfect for microbusiness owners to work together to help one another business take off. This can be done through a new lens collaborative leadership.

Entrepreneurs in microbusiness need to understand that entrepreneurship is a team sport and the only way to survive and grow is to build a solid team. The mindset of microbusiness owners must shift if there is going to be more progress in the field of entrepreneurship. This new mindset must be a proactive mindset that is willing to approach entrepreneurship as a collaborative leader. There are not many for-profit organizations that have embrace collaborative leadership throughout the entire organization but in pockets. Nevertheless, a nonprofit organization has taken on this leadership style and that is exactly what most businesses are for the first 5 years whether they are for-profit or not because they do not make a profit until three to five years after they start.

Miller and Miller (2012) study interviewed 13 officials of the not-for-profit organization who embrace collaborative leadership which turned the findings into eight leadership topics: authentic self-awareness; personal vision, charisma, passion; communication for understanding; relationship building; facilitate the process; forging group vision; consultative decision-making; managing for action. These eight leadership topics establish a clear vision of collaborative leadership by exposing its core attributes. A few that sticks out in the context of microbusinesses are communication for understanding, consultative decision-making, relationship building, passion, and personal vision. Miller and Miller (2012) article pointed out certain actions they found that many collaborative leaders take when functioning as a collaborative leader.

Grint (2011) stated collaborative leadership has several ideas and not just the property of one individual. This perspective could help entrepreneurs in microbusinesses to survive and grow based on owners including other experts in the environment instead of excluding them. Coworking spaces would be a tremendous environment for entrepreneurs to allow this style of leadership to benefit them and their business. Many entrepreneurs stress themselves out by trying to do everything in their business. The day to day operations, the marketing, the bookkeeping, the sales, and the telecommunication. You can be good at a lot of different things in your business, but you will only be great at one or two things. Today good is not going to cut it for microbusiness owners. Entrepreneurs in microbusiness must become great to compete, great to survive, and great to overcome the economic blows that all entrepreneurs face at one time or another.

Pearce and Conger (2003) revealed the wisdom behind collaborative leadership by stating "rather than simply following the lead of the person with the formal authority

in a situation, one should follow the lead of the person with the most knowledge regarding the situation at hand" (p. 6). Mendenhall and Marsh (2010) article on collaborative leadership focused on combing amongst group members to invent new realities. They saw power-sharing as critical to leadership: Mendenhall and Marsh (2010) article revealed: The core elements of transformation associated with collaborative leadership are worldview shifting, covenant-making, and the philosophical and emotional embracing of differences. It is only when these transformative processes are well underway within individuals that the effects of collaborative leadership skills and competencies begin to be efficacious (Mendenhall \& Marsh, 2010, p. 301).

Methodology. Fatoki (2018) study investigated the relationship between entrepreneurial resilience and the success of SMEs in South Africa using the Connor-Davidson Resilience Scale 10 (CD-RISC). Fatoki (2018) used a quantitative approach to determine the relationship between resilience and success in micro and small businesses. This study used a similar quantitative approach to determine the relationship between resilience and financial innovation in microbusinesses. Fatoki (2018) recognized the need for micro and small businesses to succeed in job creation, poverty reduction, and sustainable economic growth. The researcher realizes the need and the lack of empirical evidence focused on this need for micro and small businesses to grow to help cities, states, and even nations as Fatoki (2018) studies suggested. The relationship between resilience and financial innovation in microbusinesses is not yet sufficiently defined (Bristow \& Healy, 2017). Therefore, the research methodology for this study is quantitative, which will use statistics to analyze the relationships between resilience and financial innovation (Etchegaray \& Fischer, 2010).

Fatoki (2018) stated because of the difficulty in obtaining the population of SMEs in the study area, convenience, and snowball sampling methods were used to identify survey participants. The researcher used a convenience sampling strategy as well as to recruit from the target population. A convenience sample is a type of non-probability sampling that involves the sample being drawn from that part of the population that is selected because it is readily available and convenient (Boslaugh, 2013). Fatoki (2018) was conducted in the Central Business District of Johannesburg in South Africa while this study conducted its researcher in a business hub in Detroit called TechTown. To align with previous research and for this study, we used a 
quantitative methodology to determine the relationship between resilience and financial innovation, along with a convenience sampling strategy to recruit from the target population.

Instrumentation. Ayala and Manzano (2013) measured resilience using the Connor-Davidson Resilience Scale (CD-RISC) Spanish version using three dimensions of resilience hardiness, resourcefulness, and optimism to measure resilience. The instrument uses 9 items to measure hardiness, 7 items to measure resourcefulness, and 7 items to measure optimism. Hardiness, resourcefulness, and optimism showed adequate parameters for convergent validity and internal reliability. Hardiness composite reliability was 0.88 and convergent validity was 0.57 . Resourcefulness composite reliability was 0.87 and convergent validity was 0.62 . Optimism composite reliability was 0.80 and convergent validity was 0.54 . Fatoki (2018) study investigated the relationship between entrepreneurial resilience and the success of SMEs in South Africa using the ConnorDavidson Resilience Scale 10 (CD-RISC). This scale measures resilience using hardiness, resourcefulness, and optimism as well. Therefore, this study used the Connor-Davidson Resilience Scale (CD-RISC) to obtain an accurate measurement of resilience.

The city of Detroit is still striving to come back from a massive blow to the city and entrepreneurs' faith and microbusinesses are needed along with other businesses to help restore the city. Korkmaz, (2017) stated, after such an intense economic crisis, Detroit's economy has turned around very slowly in the last ten years. For the inner city in Detroit to bounce back quickly there is a need to determine if the relationship between resilience and financial innovation would help. Resilience can grow in entrepreneurs, and it promotes business survival or growth following a crisis (Doern, 2017) while financial innovation has been seen to grow businesses (Winterhalter et al., 2016).

The relationship between resilience and financial innovation in a shared space environment could shed light on entrepreneurs in microbusinesses' ability to grow faster and quicker instead of dissolving more quickly due to lack of resources. This unique proposal approach to financial innovation and resilience in microbusiness will also benefit practitioners who never thought to put some of their scares resources towards resilience to include it in their competitive strategy to survive. Microbusiness is always going to have to deal with different hardships, unseen problems, and visible problems. Nevertheless, in a shared space environment that promotes creativity, learning, collaboration, and financial innovation could help overcome certain hardships and adversities.

The purpose of this quantitative correlational study is to determine if and to what extent there is a relationship between resilience and financial innovation in the microeconomics business market in the state of Michigan in the United States. This is a correlational research study design. The geographic location would be in Detroit, Michigan. The target population considered is owners of microbusinesses in or near the downtown Detroit area in buildings where many microbusinesses entrepreneurs have rented space to run their business. The relationship between the two variables for the study is the independent variable resilience and the dependent variable financial innovation. Connor and Davidson (2003) define resilience as the embodiment of personal qualities that enable one to thrive in the face of adversity. De Ven et al. cc (2000) defines financial innovation as the introduction of a new idea that brings value to the company. Resilience and financial innovation are both argued to be critical drivers of the firm's success (Zach (2016), Fisher, Maritz, \& Lobo, (2016)). However, there is limited empirical evidence on the relationship between entrepreneur individual resilience and financial innovation in microbusiness (Roper, Hewitt-Dundas (2017) \& Bristow, Healy (2017). Identifying the relationship between these two variables could help entrepreneurs in microbusinesses cope with their challenges, survive in their business, and grow their business by focusing more on developing individual resilience and financial innovation.

\section{Summary}

The review of the literature analyzed the phenomenon of entrepreneur resilience and unfolded several themes, including resilience characteristics, microbusinesses, society problems, coworking spaces, business development, social capital, financial innovation, and collaborative financial leadership. The growing focus area of entrepreneur resilience which fits inside of entrepreneurial cognitions possesses many unexplained processes, based on the entrepreneur's behavior, and decisions it has created are opportunities for researchers (Awotoye \& Singh, 2017). Carland, Hoy, Boulton, and Carland (1984) and Busenitz and Barney (1997) using individual entrepreneur's traits to extend entrepreneurship literature was the start. Shaver and Scott (1991) move the literature forward with analyzes of the psychological processes of entrepreneurs. Mitchell et al. 
(2002) extended it by expounding on entrepreneurial cognition searching for the answer to the question: "How do entrepreneurs think"? Finally, this literature answers the call of Shepard (2015) article for exploring entrepreneurial cognition while incorporating a focus on microbusiness growth. There is limited quantitative literature on entrepreneur resilience and its relationship with small businesses. This led to the problem statement: It is not known if and to what extent there is a relationship between resilience and financial innovation in the microeconomics business market in the state of Michigan in the United States.

This chapter analyzed the concept and theories connected to entrepreneur resilience. The concepts that framed this research included the models of resilience, adaptation, and financial innovation. Each of these concepts brought to light different aspects of entrepreneurs' resilience in microbusiness which lack resources and resilience. The primary components of the phenomenon were its proactive unique viewpoint that allows researchers to see the light of resilience as a catalyze and proactive forces in an entrepreneur's lives (Bernard \& Barbosa, 2016).

The conceptual framework section analyzed the literature on theories related to the phenomenon. The two theories that used for this study are the resilience theory by Connor \& Davidson (2003) and the individual innovative behavior theory by Scott and Bruce, (1994). The resilience theory model has five components: personal competence, acceptance of change, trust, control, and spiritual influence (Connor \& Davidson, 2003). The theory of individual innovative behavior draws on the idea that any innovative venture and outcome results from the activity of creative individuals who propose new ideas and engage in collaborative efforts toward evaluation and implementation (Kanter, 1988). The theory of individual innovative behavior has four components: individuals, leaders, workgroups, and the climate of financial innovation (Scott and Bruce, 1994).

Author Contributions: conceptualization, Dr. Brown E., Dr. K. Kasztelnik; methodology, Dr. Brown E., Dr. K. Kasztelnik; validation, Dr. K. Kasztelnik; formal analysis, Dr. Brown E., Dr. K. Kasztelnik; investigation, Dr. Brown E., Dr. K. Kasztelnik; resources, Dr. Brown E., Dr. K. Kasztelnik; data curation, Dr. Brown E., Dr. K. Kasztelnik; writing - original draft preparation, Dr. Brown E., Dr. K. Kasztelnik; writing review and editing, Dr. Brown E., Dr. K. Kasztelnik; visualization, Dr. Brown E., Dr. K. Kasztelnik; supervision, Dr. K. Kasztelnik; project administration, Dr. K. Kasztelnik.

\section{References}

1. Adeniran, T., \& Johnston, K. (2012). Investigating the dynamic capabilities and competitive advantage of South African SMEs. Afr. J. Bus. Manag. 6, 4088-4099. Retrieved from: http://www.academia.edu/4983218/ Investigating the dynamic capabilities and competitive advantage of South African SMEs

2. Agyapong, F. O., Agyapong, A., \& Poku, K. (2017). Nexus between social capital performance of micro and small firms in an emerging economy: The mediating role of financial innovation. Cogent Business \& Management, 4(1). Retrieved from: https://www.tandfonline.com/doi/full/10.1080/23311975. 2017.1309784?scroll $=$ top\& needAccess $=$ true

3. Anwar, M. N., \& Daniel, E. M. (2017). Ethnic entrepreneurs and online home-based Business: an exploratory study. Journal of Global Entrepreneurship Research, 7(1), 6. Retrieved from: https://journaliger.springeropen.com/articles/10.1186/s40497-017-0065-3

4. Angel, H., \& Van de Ven, A. H. (2000). Research on the management of financial innovation. Cambridge, MA: Ballinger. Retrieved from: https://www.researchgate.net/publication/258697378 PROBLEMS OF INNOVATION DIFFUSION AMONG COMPANIES FROM WESTERN POMERANIA REGION RESULTS OF EMPIRICAL RESEARCH

5. Armstrong, J. (2010). Naturalistic inquiry. In N. J. Salk (Ed.), Encyclopedia of research design (pp. 880885). Thousand Oaks, CA: SAGE. Retrieved from: https://www.academia.edu/9605023/Naturalistic_Inquiry_and the Satu ration_Concept_A_Research Note

6. Awotoye, Y., \& Singh, R. (2017). Entrepreneurial Resilience, High Impact Challenges, and Firm Performance. In the United States Association for Small Business and Entrepreneurship. Conference Proceedings (p. 482). United States Association for Small Business and Entrepreneurship.

7. Barzun, J., \& Graff, H.F. (1992). The modern researcher: A classic work on research and writing completely revised and brought up to date. San Diego: Harcourt Brace Jovanovich. Retrieved from: https://archive.org/details/ modernresearcher00jacq/page/n19/mode/2up 
8. Bennett, K.M. and Noyes, J. (2011) A Methodological Review of Resilience Measurement Scales. Health and Quality of Life Outcomes, 9(8). Retrieved from: https://hqlo.biomedcentral.com/articles/ 10.1186/1477-7525-9-8

9. Boone, C., De Brabander, B., \& Van Witteloostuijn, A. (1996). CEO locus of control and small firm performance: An integrative framework and empirical test. Journal of management studies, 33(5), 667700. Retrieved from: https://pure.uvt.nl/portal/files/1411185/CEO.pdf

10. Bonnet, J., El Harbi, S., \& Gazzah, F. (2017). Exploring the relationship between micro-enterprises and regional development: Evidence from Tunisia (No. 2017-14). Center for Research in Economics and Management (CREM), University of Rennes 1, University of Caen and CNRS. Retrieved from: https://econpapers.repec.org/ RePEc:tut:cremwp:2017-14

11. Boslaugh, S. (2013). Statistics in a nutshell: A desktop quick reference. Sebastopol, CA:O'Reilly Media. Retrieved from: http://www.r-5.org/files/books/computers/algo-list/statistics/data-mining/Sarah Boslaugh Paul_Watters-Statistics_in_a Nutshell-EN.pdf

12. Bristow, G., \& Healy, A. (2018). Financial innovation and regional economic resilience: an exploratory analysis. The annals of regional science, 60(2), 265-284. Retrieved from: http://orca.cf.ac.uk/102354

13. Chen, H. X. (2012). Approaches to Quantitative Research. Cork, IE: Oak Tree Press.

14. Chess, P.S. (2017). Chapter 3: Validity and reliability in qualitative research. In Grand Canyon University (Ed.), GCU doctoral research: Advanced qualitative research methods. Retrieved from http://lc.qa.gcumedia.com/res855/gcu-doctoral-research-advanced-qualitative-researchmethods/v1.1/\#/chapter/3

15. Connor, K. M., \& Davidson, J. R. (2003). Development of a new resilience scale: The Connor-Davidson resilience scale (CD-RISC). Depression and anxiety, 18(2), 76-82. Retrieved from: https://pubmed.ncbi.nlm.nih.gov/ 12964174/

16. Cramer, D. (1998). Fundamental statistics for social research. London: Routledge. Retrieved from: https://www.taylorfrancis.com/books/9780203360613

17. Cramer, D., \& Howitt, D. (2004). The SAGE dictionary of statistics. London: SAGE. Retrieved from: https://www.scirp.org/(S(351jmbntvnsjt1aadkposzje))/reference/ReferencesPapers.aspx?ReferenceID=2 123813

18. Diamond, M. A. (1996). Financial innovation and diffusion of technology: A human process. Consulting Psychology Journal: Practice and Research, 48(4), 221. Retrieved from: https://scholar.google.com/scholar_lookup?doi=10.1037\%2F1061-4087.48.4.221

19. Di Fabio, A., Giannini, M., Loscalzo, Y., Palazzeschi, L., Bucci, O., Guazzini, A., \& Gori, A. (2016). The challenge of fostering healthy organizations: An empirical tudy on the role of workplace relational civility in acceptance of change and well-being. Frontiers in psychology, 7, 1748. Retrieved from: https://www.ncbi.nlm.nih.gov/pmc/articles/PMC5116469/

20. Doane, D.P., \& Seward, L.E. (2011). Measuring Skewness. Journal of Statistics Education, 19(2), 1-18. Retrieved from: http://jse.amstat.org/v19n2/doane.pdf

21. Doern, R. (2017). Strategies for resilience in entrepreneurship: Building resources for small business survival after a crisis. Creating Resilient Economies: Entrepreneurship, Growth, and Development in Uncertain Times, Edward Elgar. Strategies for Resilience in Entrepreneurship: Building Resources for Small Business Survival After a Crisis Rachel Doern, Goldsmiths University of London. Retrieved from: https://econpapers.repec.org/bookchap/elgeechap/17125 $5 \mathrm{f} 2 . \mathrm{htm}$

22. Etchegaray, J. M., \& Fischer, W. G. (2010). Understanding Evidence-Based Research Methods: Graphical Data Analysis. HERD: Health Environments Research \& Design Journal, 3(2), 118-125. Retrieved from: http://journals.sagepub.com/doi/abs/10.1177/193758671000300210

23. Faul, F., Erdfelder, E., Lang, A.-G., \& Buchner, A. (2007). G*Power 3: A flexible statistical power analysis program for the social, behavioral, and biomedical sciences. Behavior Research Methods, 39, 175-191. Retrieved from: https://link.springer.com/article/10.3758/BF03193146

24. Faul, F., Erdfelder, E., Buchner, A., \& Lang, A.-G. (2009). Statistical power analyses using G*Power 3.1: Tests for correlation and regression analyses. Behavior Research Methods, 41, 1149-1160. Retrieved from: https://www.researchgate.net/publication/38075044_Statistical_Power_Analyses_Using_GPower_31_Te sts_for_Correlation_and Regression_Analyses

25. Fisher, R., Maritz, $\bar{A} .$, \& Lobo, A. (2016). Does individual resilience influence entrepreneurial success? Academy of Entrepreneurship Journal, 22(2), 39. Retrieved from: http://scholar.google.com/citations?user=-H8akCoAAAAJ\&hl=en 
Financial Markets, Institutions and Risks, Volume 4, Issue 3, 2020 ISSN (online) - 2521-1242 ISSN (print) - 2521-1250

26. Grant C. \& Osanloo A. (2015). Understanding, selecting, and integrating a theoretical framework in dissertation research: Creating the blueprint for your "house". Administrative Issues Journal, 4(2), 12-26. Doi: 10.5929/2014.4.2.9 Retrieved from: https://eric.ed.gov/?id=EJ1058505

27. Hagan, T. L. (2014). Measurements in quantitative research: How to select and report on research instruments. Oncology Nursing Forum, 41(4), 431-433. Retrieved from: https://pubmed.ncbi.nlm.nih .gov/24969252/

28. Kobasa, S. C. (1979). Stressful life events, personality, and health: An inquiry into hardiness. Journal of Personality and Social Psychology, 37(1), 1-11. Retrieved from: https://psycnet.apa.org/record/1980$\underline{21134-001}$

29. Korkmaz, K. A. (2017, October). Analytical Approach for Detroit Urban Redevelopment and Rehabilitation. In IOP Conference Series: Materials Science and Engineering, (245)8, 082013. IOP Publishing. Retrieved from: http://www.o-ke.cn/Public/uploads/Contribute/5ba44cd75faf9.pdf

30. Krysik, J.L \& Flynn, J. (2013). Research for effective social work practice (3rd Ed.). New York: Routledge. Retrieved from: https://doi.org/10.4324/9780203077894

31. Laerd Statistics (2017). Pearson's product-moment correlation using SPSS Statistics. Statistical tutorials and software guides. Retrieved from https://statistics.laerd.com/

32. Laub, J. (1999). Assessing the servant organization: Development of the servant organizational leadership assessment (SOLA) instrument (Doctoral Dissertation, Florida Atlantic University). Available from ProQuest Dissertation and Theses Database. (UMI No. 9921922). Retrieved from: http://olagroup.com/Images/mmDocument/Laub\%20Dissertation\%20Complete\%2099.pdf

33. Leedy, P. D., \& Ormrod, J. E. (2015). Practical research: Planning and design (11th ed). Boston, MA: Pearson Education. Retrieved from: https://www.pearson.com/us/higher-education/product/LeedyPractical-Research-Planning-and-Design-11th-Edition/9780133741322.html

34. Lincoln, Y. S., \& Guba, E. G. (1985). Naturalistic inquiry. Newbury Park, CA: SAGE. Retrieved from: https://methods.sagepub.com/book/the-handbook-of-social-work-research-methods-2e/i2299.xml

35. Liu, X. (2010). Using and developing measurement instruments in science education: A Rasch modeling approach. Charlotte, NC: Information Age. Retrieved from: https://eric.ed.gov/?id=ED510146

36. Lyon, C. E., Papa, C. M., \& Wilson Jr, R. L. (1991). Effect of feed withdrawal on yields, muscle pH, and texture of broiler breast meat. Poultry Science, 70(4), 1020-1025. Retrieved from: https://www.sciencedirect.com/ science/article/pii/S0032579119331785

37. Manzano, G., \& Ayala, J. C. (2013). Psychometric properties of the Connor-Davidson Resilience Scale in a Spanish sample of entrepreneurs. Psicothema, 25(2), 245-251. Retrieved from: https://pubmed.ncbi.nlm. nih.gov/ 23628541

38. Mason, M. (2010). Sample size and saturation in Ph.D. studies using qualitative interviews. Forum: Qualitative Research 11(3). Retrieved from: http://www.qualitative-research.net/index.php/ fqs/article/view/1428

39. McCrae, R. R. (2015). A more nuanced view of reliability: Specificity in the trait hierarchy. Personality and Social Psychology Review, 19(2), 97-112. Retrieved from: https://psycnet.apa.org/record/201515978-002

40. Miller D., Toulouse J.M. (1986). Chief executive personality and corporate strategy and structure in small firms, Management Science, 32(11), 1389-1409. Retrieved from: https://econpapers.repec.org/RePEc: inm:ormnsc:v: 32:y:1986:i:11:p:1389-1409

41. Miller D., DE Vries M.F.K., Toulouse J.M. (1982). Top executive locus of control and its relationship to strategy-making, structure, and environment, Academy of Management Journal, 25(2), 237- 253. Retrieved from: https://journals.sagepub.com/doi/abs/10.1111/etap.12216

42. Moenkemeyer, G., Hoegl, M., \& Weiss, M. (2012). Innovator resilience potential: A process perspective of individual resilience as influenced by financial innovation project termination. Human Relations, 65(5), 627-655. Retrieved from: https://journals.sagepub.com/doi/abs/10.1177/0018726711431350

43. Mohammadkazemi, R., Rasekh, N., \& Navid, M. (2016). The effect of entrepreneurial competencies on financial innovation: A case study of professional sport clubs. International Business Research, 9(11), 5764. Retrieved from: http://www.ccsenet.org/journal/index.php/ibr/article/view/62333

44. Mugerwa, E. A. (2013). Entrepreneurial competencies, financial innovation, and firm performance: a case of SMEs in the Kawempe division Kampala district. Masters dissertation, Makerere University, Kampala, Uganda. Retrieved from: http://makir.mak.ac.ug/bitstream/handle/10570/3851/mugerwa-cobamsmasters-abstract.pdf? sequence $=5 \&$ is Allowed $=y$ 
45. Powell, E. E., \& Baker, T. (2011). Beyond making do: Toward a theory of entrepreneurial resourcefulness. Frontiers of Entrepreneurship Research, 31(12), 375-388. Retrieved from: https://eric.ed.gov/ ?id=ED510146

46. Publication Manual of the American Psychological Association. (2010). Washington, DC: American Psychological Association. (6th edition) (ISBN 10: 1-4338-0559-6; ISBN 13: 978-1-4338-0561-5; ISBN 10: 1-4338-0561-8). Retrieved from: https://www.sciencedirect.com/science/ article/pii/ S0032579 119331785

47. Reinmoeller, P., \& Van Baardwijk, N. (2005). The link between diversity and resilience. MIT Sloan Management Review, 46(4), 61. Retrieved from: https://pubmed.ncbi.nlm.nih.gov/23628541

48. Renzl, B. (2008) Trust in Management and Knowledge Sharing: The Mediating Effects for Fear and Knowledge Documentation, Omega, 36(2), 206-220. Retrieved from: https://econpapers.repec.org/ RePEc:eee:jomega: v:36:y:2008:i:2:p:206-220

49. Roper, S., \& Hewitt-Dundas, N. (2017). Investigating a neglected part of Schumpeter's creative army: what drives new-to-the-market financial innovation in micro-enterprises? Small Business Economics, 49(3), 559-577. Retrieved from: https://link.springer.com/article/10.1007/s11187-017-9844-z

50. Rutter, M. (1985). Resilience in the face of adversity: Protective factors and resistance to a psychiatric disorder. The British Journal of Psychiatry, 147(6), 598-611. Retrieved from: https://pubmed.ncbi.nlm. nih.gov/3830321

51. Sa'ari, H. (2013). Identifying Entrepreneurial Competencies Which Lead to Innovative Performance in Malaysian Academic Libraries. Paper read at 4th International Conference on Information Management and Evaluation (ICIME) in Ho Chi Min City, Vietnam on 13-14 May. Retrieved from: https://www.academia.edu/2640897/Identifying_Entrepreneurial_Competencies_Which_Lead_To_Innov ative Performance in Malaysian Academic Libraries

52. Sameer, M. Yomna (2018). Innovative behavior and psychological capital: Does positivity make any difference? Journal of Economics and Management. 32(2), 75-101. Retrieved from: http://cejsh.icm.edu.pl/cejsh/element/bwmeta1.element.cejsh-60596cd3-1234-4416-9ff3-9115da12a9f7

53. Simoni, P. S., \& Paterson, J. J. (1997). Hardiness, coping, and burnout in the nursing workplace. Journal of Professional Nursing, 13(3), 178-185. Retrieved from: https://pubmed.ncbi.nlm.nih.gov/9167407/

54. Simon, Marilyn K. (2011). Dissertation and scholarly research: Recipes for success, Seattle, WA, Dissertation Success, LLC. Retrieved from: https://www.worldcat.org/title/dissertation-and-scholarlyresearch-recipes-for-success/oclc/762961545

55. Simon, Marilyn k. \& Goes, Jim (2013) Dissertation and Scholarly Research: Recipes for Success, WA: Dissertation Success LLC. Retrieved from: https:/www.worldcat.org/title/dissertation-and-scholarlyresearch-recipes-for-success/oclc/762961545

56. Singh, R. P., \& Ogbolu, M. N. (2015, January). The need to improve US business dynamism through entrepreneurship: Trends and recommendations. In the United States Association for Small Business and Entrepreneurship. Conference Proceedings (p. ZZZ1). United States Association for Small Business and Entrepreneurship. Retrieved from: https://www.usasbe.org/page/2020Conference

57. Shenton, A. K. (2004). Strategies for ensuring trustworthiness in qualitative research projects. Education for Information, 22, 63-75. Retrieved from: https://www.scirp.org/(S(czeh2tfqyw2orz553k1w0r45))/ reference/ ReferencesPapers.aspx? ReferenceID $=2112685$

58. Smallbone, D., Deakins, D., Battisti, M., \& Kitching, J. (2012). Small business responses to a major economic downturn: Empirical perspectives from New Zealand and the United Kingdom. International Small Business Journal, 30(7), 754-777. Retrieved from: https://journals.sagepub.com/doi/ $10.1177 / 0266242612448077$

59. Smith, K. B., Alford, J. R., Hibbing, J. R., Martin, N. G., \& Hatemi, P. K. (2017). Intuitive ethics and political orientations: Testing moral foundations as a theory of political ideology. American Journal of Political Science, 61(2), 424-437. Retrieved from: https://pennstate.pure.elsevier.com/en/publications/ intuitive-ethics-and-political-orientations-testing-moral-foundat

60. Squires, D. A., \& Kranyik, R. D. (1995). The comer program: changing school culture. Educational Leadership, 53(4), 29-32. Retrieved from: http:/www.ascd.org/publications/educational-leadership/ dec95/vol53/num04/ The-Comer-Program@-Changing-School-Culture.aspx

61. Strunk, W. I., \& White, E.B. (1979). The elements of style. New York: Macmillan Publishing, Inc. Retrieved from: http://www.jlakes.org/ch/web/The-elements-of-style.pdf 
62. Vingrys, A. J., \& King-Smith, P. E. (1988). A quantitative scoring technique for panel tests of color vision. Investigative Ophthalmology \& Visual Science, 29(1), 50-63. Retrieved from: https://iovs.arvojournals.org/article.aspx?articleid=2159859

63. Wargo, W.G. (2015). Identifying Assumptions and Limitations for Your Dissertation. Menifee, CA: Academic Information Center. Retrieved from: https://www.academicinfocenter.com/identifyingassumptions-and-limitations-for-your-dissertation.html

64. Weiner, B. (1985). An attributional theory of achievement motivation and emotion. Psychology. 97, 548573. Retrieved from: https://pdfs.semanticscholar.org/23db/ 126e3c39983e1f7296454463610 3c6c 313c2.pdf

65. Weinreich, N.K (1996) A more perfect union: Integrating quantitative and qualitative methods in social marketing research. Social Marketing Quarterly, 3(1), 53-58. Retrieved from: https://journals.sagepub.com/doi/abs/ 10.1177/152450049600300106

66. Wienclaw, R. A. (2015). Quantitative and Qualitative Analysis. Research Starters: Sociology. (Online Edition). Retrieved from: http://www.academicpub.com/map/items/29526.html

67. Windle, G., Bennett, K. M., \& Noyes, J. (2011). A methodological review of resilience measurement scales. Health and quality of life outcomes, $9(1), 8$. https://pubmed.ncbi.nlm.nih.gov/21294858/

68. Windle, G.,Winterhalter, S., Zeschky, M. B., Neumann, L., \& Gassmann, O. (2017). Business Models for Frugal Financial innovation in Emerging Markets: The Case of the Medical Device and Laboratory Equipment Industry. Technovation, 66, 3- 13. Retrieved from: https://ideas.repec.org/a/eee/techno/v6667y2017ip3-13.html

69. Yang, Y., \& Danes, S. M. (2015). Resiliency and resilience process of entrepreneurs in new venture creation. Entrepreneurship Research Journal, 5(1), 1. Retrieved from: https://ideas.repec.org/a/bpj/erjour/ v5y2015i1p30n1.html

70. Yi Li Feng Wei Shenggang Ren Yang Di. (2015). Locus of control, psychological empowerment and intrinsic motivation related to performance, Journal of Managerial Psychology, 30(4), 422 - 438. Retrieved from: http://ir.nsfc.gov.cn/paperDownload/1000013779239.pdf

71. Yilmaz, K. (2013). Comparison of quantitative and qualitative research traditions: Epistemological, theoretical, and methodological differences. European Journal of Education, 48(2), 311-325. DOI:10.1111/ejed.12014. Retrieved from: https://onlinelibrary.wiley.com/doi/abs/10.1111/ejed.12014

72. Young, S., \& Bruzzone, M. (2018). Feeling the pulse of the city: racial liberalism and the political geographies of tension in postwar Detroit. Urban Geography, 1- 19. Retrieved from: https://www.tandfonline.com/doi/abs/10.1080/02723638.2018.1452399

73. Zach, F. (2016). Collaboration for financial innovation in tourism organizations: leadership support, financial innovation formality, and communication. Journal of Hospitality \& Tourism Research, 40(3), 271-290. Retrieved from: https://journals.sagepub.com/doi/abs/10.1177/1096348013495694 